\title{
Activity of antifungal drugs and Brazilian red and green propolis extracted with different methodologies against oral isolates of Candida spp.
}

\author{
Ana Rita Sokolonski ${ }^{1}$, Maísa Santos Fonseca ${ }^{1}\left[\right.$, Bruna Aparecida Souza Machado ${ }^{2}$,

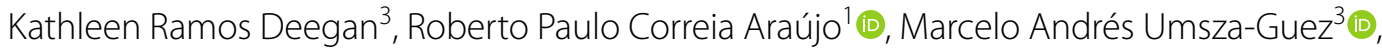 \\ Roberto Meyer ${ }^{1}\left[0\right.$ and Ricardo W. Portela ${ }^{3^{*}}$ (])
}

\begin{abstract}
Background: Oral candidiasis is an opportunistic disease caused by fungi of the Candida genus. The occurrence of Candida spp. resistance to the commercial antifungal drugs points to the search for alternative treatments. Propolis has been successfully used in the treatment of infectious diseases for centuries. It has been proposed that an ultrasound pretreatment in the propolis extraction protocol can enhance the concentrations of molecules with antimicrobial activities in the final extract. Thus, this study aimed to compare the antifungal activity against oral Candida spp. isolates of green and red propolis extracts submitted or not to an ultrasound pretreatment before the extraction procedure.

Methods: Candida spp. were isolated from denture stomatitis lesions and identified by sequencing. Oral Candida spp. isolates and reference strains were submitted to broth microdilution assays using commercial antifungals and Brazilian green and red propolis extracts submitted or not to an ultrasound pretreatment. Minimal Inhibitory Concentrations (MIC) and Minimal Fungicide Concentrations (MFC) were determined and biofilm formation interference was evaluated for resistant isolates.

Results: C. albicans, Candida tropicalis and Candida dubliniensis were isolated from denture stomatitis lesions. Growth inhibition was observed in all Candida isolates incubated with all green and red propolis extracts. At lower doses, red propolis extracts presented significant antifungal activity. The ultrasound pretreatment did not promote an increase in the antifungal activity of green or red propolis. Three isolates, which were highly resistant to fluconazole and itraconazole, were susceptible to low doses of red propolis extracts. These same three specimens had their biofilm formation inhibted by red propolis ethanolic extract.
\end{abstract}

Conclusions: Thus, red propolis can be faced as a promising natural product to be used in the auxiliary antifungal therapy of denture stomatitis.

Keywords: Antifungal activity, Fungal biofilm, Green propolis, Oral candidiasis, Red propolis

*Correspondence: rwportela@ufba.br

${ }^{3}$ Departamento de Biotecnologia, Instituto de Ciências da Saúde,

Universidade Federal da Bahia, Avenida Reitor Miguel Calmon s/n, Vale do

Canela, Salvador, Bahia State 40110-100, Brazil

Full list of author information is available at the end of the article

\section{Background}

An estimated 8.7 million eukaryotic species live on Earth, of which fungi are approximately $7 \%$ [1], and about 600 fungal species are human pathogens [2]. Fungi can cause 
oral infections $[3,4]$, with Candida spp. being the most important etiologic agent of oral diseases [4]. Oral candidiasis is an opportunistic infection that develops in the presence of several predisposing conditions, such as immunodeficiencies, endocrine disorders and poor oral hygiene [5]. C. albicans is the most frequent agent found in oral candidiasis, but other Candida species, such as $C$. parapsilosis, C. tropicalis, C. glabrata, C. krusei, C. pseudotropicalis and C. guilliermondii, known as non-Candida albicans species (NCA), have been isolated from several clinical cases of the disease [4].

Oral candidiasis associated with denture stomatitis are difficult to treat, and high rates of recurrence are reported $[6,7]$. The most common treatment for denture stomatitis includes denture hygiene associated with the use of synthetic antifungal drugs [8]. However, the currently available drugs are not fully effective [9], as shown by the occurrence of resistant strains, infection relapse due to the unappropriated use of drugs and the persistence of the fungal infection even after treatment [10]. Furthermore, Candida spp. is known to be a competent biofilm-forming microorganism, and this situation is correlated with an enhanced resistance to antifungals [11-13]. The formation of biofilm by Candida spp. is considered a factor that contributes to the recurrence of oral candidiasis and development of chronic infections [14]. In this context, the antimicrobial activity of natural derivatives, such as propolis, has been seen as a promising new therapeutic strategy [7].

Propolis has antibacterial [15], anti-caries [16], antiinflammatory [17], antioxidant [4], antifungal [18], immunomodulatory [19], anticancer and antiproliferative properties [20]. More than 300 different components were identified in samples of propolis from different origins [21]. In Brazil, 14 different types of propolis were classified based on their geographic origin, color, and physicochemical properties [22-24]. The traditional methods for obtaining or fractioning propolis extracts are distillation (with or without vacuum), extraction by liquid solvents, chromatography, adsorption, and membrane-selective processes [25]. Among these, ethanol is commonly used as a consequence of its chemical affinity to several propolis compounds with important biological activities [26]. With the objective to improve the concentration of bioactive compounds in propolis extracts and to enhance the reproducibility of the extraction method, the use of ultrasound as a pretreatment of the extraction process has been proposed [27]. Both et al. [28] found that the use of an ultrasound-assisted technology for the extraction of polyphenols from black tea enhanced the yield of this compound by $15 \%$.

Considering the need for more accurate treatments for oral candidiasis, the increasing resistance profile of Candida spp. strains and the promising use of ultrasound-assisted extraction technologies, the present study aimed to compare the antifungal activity of green and red propolis extracts obtained with and without ultrasound as an extraction pretreatment against oral Candida isolates.

\section{Methods}

\section{Fungal samples and ethical aspects}

The clinical isolates used in this study were obtained from patients screened by dentistry professionals at the Dentistry Ambulatory of the UNIME University, Salvador, Brazil. The samples were collected from palate denture stomatitis lesions suggestive of oral candidiasis using sterile swabs, inoculated on Sabouraud dextrose agar (SDA) (HIMEDIA, Mumbai, India) supplemented with $0.2 \%$ chloramphenicol, and incubated at $37^{\circ} \mathrm{C}$ for $24-48 \mathrm{~h}$ [29]. The colonies were then isolated and maintained by weekly reinoculations in the same media. As references, we used four $C$. albicans strains kindly supplied by the Fundação Oswaldo Cruz (FIOCRUZ - IOC 2508, IOC 2517, IOC 3703 and IOC 3704).

The Ethics Committee of the Institute of Health Sciences, Federal University of Bahia, Salvador, Brazil (protocol number 2.118.563) approved this research.

\section{Identification of the fungal isolates}

All clinical isolates were inoculated in CHROMagar ${ }^{\mathrm{TM}}$ Candida $^{\circledR}$ for presumptive differentiation of the Candida species as described by Madhavan et al. [30]. To confirm the identifications, DNA sequencing of ITS and nuclear large subunit rDNA (LSU) regions was carried out. Briefly, the extraction of the genomic DNAs of the Candida spp. clinical isolates was performed using the FastDNA Spin Kit (Mp Biomedicals, Solon, OH, USA). Polymerase chain reactions (PCR) were performed using the primers ITS4 and ITS5 for the amplification of the complete internal transcribed region 26, and LROR and LR7 for the amplification of the LSU region (Mycology Lab - Duke University | Duke Mycology, 2019) [31]. All PCR reactions were performed using Quatro G Taq DNA polymerase (Porto Alegre, RS, Brazil) in a final volume of $50 \mu \mathrm{L}$, containing $10 \mu \mathrm{l}$ of Quatro G buffer, $3.0 \mu \mathrm{l} \mathrm{MgCl}$ $2(50 \mathrm{mM}), 1 \mu \mathrm{l}$ DNTP $(10 \mathrm{mM}), 1 \mu \mathrm{l}$ forward primer (10 pmol), $1 \mu \mathrm{l}$ reverse primer $(10 \mathrm{pmol}), 1 \mu \mathrm{l}$ DMSO, $1.5 \mu \mathrm{l} \mathrm{BSA}(1 \mu \mathrm{g} / \mu \mathrm{L}), 5 \mu \mathrm{L}$ betaine $(5 \mathrm{M}), 0.2 \mu \mathrm{L}$ Taq $5 \mathrm{U} /$ $\mu \mathrm{L}), 24.8 \mu \mathrm{L}$ sterile water and $1 \mu \mathrm{L}$ DNA template. The reactions were carried out in thermocycler as following: $2 \mathrm{~min}$ at $94^{\circ} \mathrm{C}, 35$ cycles of $1 \mathrm{~min}$ at $94^{\circ} \mathrm{C}, 1 \mathrm{~min}$ at $55^{\circ} \mathrm{C}$, $1 \mathrm{~min}$ at $72^{\circ} \mathrm{C}$, and a final extension of $5 \mathrm{~min}$ at $72^{\circ} \mathrm{C}$.

Subsequently, the ethanol/EDTA $125 \mathrm{mM}$ precipitation protocol was used to obtain the purified PCR products. The DNA sequencing was executed on 3130xl automated 
sequencer (Applied Biosystems, Life Technologies, Carlsbad, CA, USA). Consensus sequences were submitted to the Basic Local Alignment Search Tool (BLAST) for the species identification, based on the similarity analysis with nucleotide sequences from the National Center for Biotechnology Information (NCBI) GenBank database.

\section{Propolis samples}

The red propolis was collected in the state of Bahia, Brazil, and the green propolis was collected in the state of Minas Gerais, Brazil. Four different propolis extracts were used in this experiment. The ethanolic green and red propolis extracts were obtained using conventional methods [20, 22]; briefly, frozen red and green propolis were crushed and sieved (60 mesh), with a final particle size of approximately $0.250 \mathrm{~nm}$, and homogenized $2 \mathrm{~g}$ samples of each propolis were extracted with ethanol $(15 \mathrm{~mL}, 80 \%)$ by mixing the samples for $30 \mathrm{~min}$ under constant agitation in an incubation shaker (MA 420/ MARCONI-Brazil) at $70^{\circ} \mathrm{C}$ and $710 \mathrm{rpm}$. The extract was recovered by centrifugation for $11 \mathrm{~min}$ at $8800 \mathrm{rpm}$ and $5{ }^{\circ} \mathrm{C}$. Then, an additional centrifugation step was performed with $10 \mathrm{~mL}$ of ethanol $(80 \%)$. The supernatant was collected, homogenized, and kept at $50{ }^{\circ} \mathrm{C}$ until completely dry. Afterwards, the extracts were stored in tubes, wrapped in aluminum foil at inert atmospheric conditions $\left(\mathrm{N}_{2}\right)$ to avoid degradation. All extracts were kept at $5^{\circ} \mathrm{C}$ until use. The other two extracts were obtained using the same method, but with the inclusion of a pretreatment with ultrasound at $50^{\circ} \mathrm{C}$ for $20 \mathrm{~min}$, according to Reis and collaborators [32]. The quantification of p-coumaric acid, artepilin C, formononetin and kaempferol in the extracts was performed using a high-performance liquid chromatography (HPLC) system equipped with an automatic injector and diode array detector (DAD). The content of total phenolic compounds was achieved based on the reaction with the Folin-Ciocalteau reagent, followed by spectrophotometry analysis at $765 \mathrm{~nm}$. The content of total flavonoid compounds was determined using a method based on the reaction with a $2 \%$ methanol solution of aluminum chloride, along with a quercetin standard curve (5 to $105 \mu \mathrm{g} / \mathrm{mL}$ ), followed by spectrophotometry analysis at $415 \mathrm{~nm}$. These results, as defined by previous studies [20,32], are shown at the Supplementary Table 1 . All the propolis samples were obtained from the Apis mellifera bee species.

\section{Broth microdilution assay}

The fungicidal activity of commercial antifungal drugs and Brazilian green and red propolis extracts were evaluated using the broth microdilution assay, as described by the M27-A3 protocol from the Clinical Laboratory Standards Institute [33]. Briefly, the yeasts were resuspended in sterile $0.9 \%$ saline solution and adjusted by spectrophotometry to a $0.8-1.0$ optical density $(530 \mathrm{~nm})$, which corresponds to 0.5 on the McFarland scale. Subsequently, the yeasts were diluted 1:50 in sterile saline solution and then diluted 1:20 in RPMI 1640 culture medium (Sigma Aldrich, St Louis, MO, USA) supplemented with $2 \%$ glucose [34] for the inoculum obtaining [33].

The four different propolis extracts used in this study, green propolis extract without ultrasound pretreatment (GP_EtOH), green propolis extract with ultrasound pretreatment (GP_US), red propolis extract without ultrasound pretreatment (RP_EtOH) and red propolis extract with ultrasound pretreatment (RP_US), were dissolved in dimethyl sulfoxide (DMSO) and then serially diluted in $1 \%$ DMSO (concentration ranging from 0.015625 to $8 \mathrm{mg} / \mathrm{mL}$ ). Commercial antifungal agents were used as reference drugs, as follows: fluconazole, with concentrations ranging from 0.125 to $64 \mu \mathrm{g} / \mathrm{mL}$; itraconazole, ketoconazole, nystatin and amphotericin $\mathrm{B}$, with concentrations ranging from 0.0313 to $16 \mu \mathrm{g} /$ $\mathrm{mL}$.

The inoculum was added to 96-well sterile culture plates at $100 \mu \mathrm{L}$ per well, followed by the addition of the commercial fungicides and propolis extracts in different concentrations. As a negative control, it was used pure RPMI 1640 media with propolis extracts and antifungals at different concentrations, but without the inoculum. As a positive control, culture media with the fungal inoculum and without any treatment was used. The plates were then incubated for $48 \mathrm{~h}$ at $37^{\circ} \mathrm{C}$. Then, the Candida spp. growth was assessed using a spectrophotometer (Thermo Scientific, USA) at $625 \mathrm{~nm}$. Each combination of inoculum and propolis or fungicide treatment was performed in triplicate, and the entire procedure was repeated twice.

The minimum inhibitory concentration (MIC) value, which represented the lowest concentration that inhibited $100 \%$ of the fungal growth, was determined by the minimum concentration of propolis or antifungal that resulted in no optic densitometry (OD) reading above the negative control OD value. For the determination of the minimum fungicide concentration (MFC - minimal drug concentration able to kill $100 \%$ of the yeasts), aliquots from each well of the broth microdilution assay were plated in SDA and then incubated at $37^{\circ} \mathrm{C}$ for additional $48 \mathrm{~h}$. Thus, the lowest concentration that revealed no visible fungal growth was determined as the MFC. According to the M27-S4 document [35], the breakpoint for fluconazole was considered for the classification of all isolates according to the corresponding MIC (at $\mu \mathrm{g} / \mathrm{mL}$ ) as follows: resistant $(\mathrm{R}) \geq 8$; dose-dependent susceptible $(\mathrm{SDD})=4$; susceptible $(\mathrm{S}) \leq 2$. For itraconazole, it was considered the M27-A3 document classification [33]. 


\section{Biofilm interference assay}

To evaluate the propolis activity against biofilm formation, the ethanolic red propolis extract (RP_EtOH) was tested against three clinical isolates: C. albicans PAC 8, C. dubliniensis PAC 1, and C. tropicalis PAC 15. These species were chosen because of its different susceptibility to RP_EtOH, as determined by the microdilution test. The ability of RP_EtOH to inhibit biofilm formation was evaluated as previously described [36]. Briefly, the strains were incubated in Sabouraud Dextrose Broth at $37^{\circ} \mathrm{C}$ in a shaker at $250 \mathrm{rpm}$ for $15 \mathrm{~h}$. The cultures had the cell density adjusted to an $\mathrm{OD}_{600}$ of $0.38-0.5$ with RPMI media and then added to a 96 well plate. The plate was incubated in a shaker at $250 \mathrm{rpm}$ at $37^{\circ} \mathrm{C}$ for $90 \mathrm{~min}$. After that time, the media was aspirated, the wells were washed with PBS and RP_EtOH diluted in RPMI (concentrations ranging from 1 to $16 \mathrm{mg}$ / $\mathrm{mL}$ ) was added. $24 \mathrm{~h}$ later, the optical density was read in a spectrophotometer at $570 \mathrm{~nm}$. The interference rates in \% were obtained using the following formula [37]:

$$
\begin{aligned}
& \text { [(OD570 of Candida spp. Treated with RP_EtOH } * 100) / \\
& \left.\mathrm{OD}_{570} \text { of non }- \text { treated Candida spp. }\right]-100
\end{aligned}
$$

\section{Results}

Identification of the Candida species isolated from denture stomatitis cases

The twelve oral cavity Candida clinical isolates were phenotypically identified using CHROMagar ${ }^{\mathrm{TM}}$ Candida (data not shown) and Sanger sequencing (Tables 1 and 2). Our results showed the presence of three Candida species with different frequencies. $C$. albicans was the most frequent isolated species $(58.33 \%-7 / 12)$, followed by $C$. tropicalis $(33.33 \%-4 / 12)$ and C. dubliniensis being the less abundant of the isolated species $(8.33 \%-1 / 12)$.

\section{Susceptibility to the commercial antifungal drugs}

The results showed that the reference strains and the clinical isolates present distinct resistance patterns for the three azoles antifungal drugs used in this study (fluconazole, ketoconazole and itraconazole). The four $C$. albicans reference strains were all susceptible to fluconazole, with MIC ranging from 0.125 to $0.5 \mu \mathrm{g} / \mathrm{mL}$. The results of $C$. albicans susceptibility to fluconazole showed that four (4/7) isolates were susceptible (MIC $\leq 2 \mu \mathrm{g} / \mathrm{mL})$, two $(2 / 7)$ were dose-dependently susceptible $(\mathrm{S}-\mathrm{DD})(\mathrm{MIC}=4 \mu \mathrm{g} / \mathrm{mL})$ and one $(1 / 7)$ was resistant $(\mathrm{MIC}=16 \mu \mathrm{g} / \mathrm{mL})$ (Table 1). Thus, $14.28 \%$ of the C. albicans clinical isolates presented resistance to fluconazole.

Table 1 MIC and MFC values obtained for Candida spp. reference strains and clinical isolates incubated with commercial fungicides (fluconazole, ketoconazole, itraconazole, nystatin and amphotericin B). Candida spp. strains and isolates were incubated with different concentrations of the fungicides, as suggested by the M27-A3 protocol from the CLSI (2008). MIC - Minimal Inhibitory Concentration;

\begin{tabular}{|c|c|c|c|c|c|c|c|c|c|c|c|}
\hline \multirow[t]{3}{*}{ Isolate } & \multirow[t]{3}{*}{ Species } & \multirow{2}{*}{\multicolumn{2}{|c|}{$\frac{\text { Fluconazole }}{(\mu \mathrm{g} / \mathrm{mL})}$}} & \multirow{2}{*}{\multicolumn{2}{|c|}{$\frac{\text { Ketoconazole }}{(\mu \mathrm{g} / \mathrm{mL})}$}} & \multirow{2}{*}{\multicolumn{2}{|c|}{$\frac{\text { Itraconazole }}{(\mu \mathrm{g} / \mathrm{mL})}$}} & \multirow{2}{*}{\multicolumn{2}{|c|}{$\frac{\text { Nystatin }}{(\mu \mathrm{g} / \mathrm{mL})}$}} & \multirow{2}{*}{\multicolumn{2}{|c|}{$\frac{\text { Amphotericin B }}{(\mu \mathrm{g} / \mathrm{mL})}$}} \\
\hline & & & & & & & & & & & \\
\hline & & MIC & MFC & MIC & MFC & MIC & MFC & MIC & MFC & MIC & MFC \\
\hline 2508 & C. albicans & $0.125(\mathrm{~S})$ & 0.125 & 0.03125 & 0.03125 & $0.03125(\mathrm{~S})$ & 0.03125 & 4 & 4 & 1 & 1 \\
\hline 2517 & C. albicans & $0.25(\mathrm{~S})$ & 0.25 & 0.03125 & 0.03125 & $0.125(\mathrm{~S})$ & 0.0125 & 4 & 8 & 1 & 1 \\
\hline 3703 & C. albicans & $0.125(\mathrm{~S})$ & 0.125 & 0.03125 & 0.03125 & $0.03125(S)$ & 0.03125 & 4 & 4 & 0.5 & 0.5 \\
\hline 3704 & C. albicans & $0.5(\mathrm{~S})$ & 0.5 & 0.03125 & 0.0625 & $0.03125(\mathrm{~S})$ & 0.03125 & 2 & 4 & 0.5 & 0.5 \\
\hline PAC 01 & C. dubliniensis & 32 (S-DD) & $>64$ & 0.03125 & 0.125 & $8(R)$ & $>16$ & 2 & 4 & 2 & 2 \\
\hline PAC 02 & C. tropicalis & $2(\mathrm{~S})$ & 16 & 0.03125 & 0.125 & 0.25 (S-DD) & 0.5 & 2 & 4 & 2 & 2 \\
\hline PAC 04 & C. tropicalis & $0.125(\mathrm{~S})$ & 0.5 & 0.03125 & 0.03125 & $0.03125(\mathrm{~S})$ & 0.03125 & 0.5 & 2 & 0.25 & 0.5 \\
\hline PAC 05 & C. tropicalis & $8(R)$ & $>64$ & 0.25 & $>16$ & $1(\mathrm{R})$ & $>16$ & 2 & 4 & 2 & 4 \\
\hline PAC 06 & C. albicans & $0.25(S)$ & 2 & 0.0625 & 0.125 & $0.0625(S)$ & 0.5 & 4 & 4 & 2 & 2 \\
\hline PAC 08 & C. albicans & $1(\mathrm{~S})$ & 8 & 0.03125 & 0.125 & 0.25 (S-DD) & 2 & 2 & 4 & 2 & 2 \\
\hline PAC 13 & C. albicans & $0.5(\mathrm{~S})$ & 16 & 0.03125 & $>16$ & $0.0625(\mathrm{~S})$ & 0.25 & 1 & 4 & 0.5 & 2 \\
\hline PAC 15 & C. tropicalis & $2(\mathrm{~S})$ & $>64$ & 0.03125 & $>16$ & $2(\mathrm{R})$ & 8 & 1 & 4 & 2 & 2 \\
\hline PAC 17 & C. albicans & $16(\mathrm{R})$ & $>64$ & 0.03125 & $>16$ & $2(\mathrm{R})$ & $>16$ & 16 & $>16$ & 4 & 4 \\
\hline PAC 18 & C. albicans & $1(\mathrm{~S})$ & $>64$ & 0.03125 & $>16$ & 0.25 (S-DD) & $>16$ & 16 & 16 & 1 & 2 \\
\hline PAC 19 & C. albicans & 4 (S-DD) & 16 & 0.125 & 1 & $1(\mathrm{R})$ & 8 & 8 & 8 & 0.5 & 0.5 \\
\hline PAC 20 & C. albicans & 4 (S-DD) & $>64$ & 0.0625 & $>16$ & $1(\mathrm{R})$ & $>16$ & 4 & 16 & 0.25 & 0.5 \\
\hline
\end{tabular}
MFC - Minimal Fungicidal Concentration; (S) - Susceptible; (S-DD) - Dose-dependent Susceptibility; (R) - Resistant 
Table 2 MIC and MFC values obtained for Candida spp. reference strains and clinical isolates incubated with different concentration of four propolis extracts. Candida spp. strains and clinical isolates were incubated for $48 \mathrm{~h}$ with different concentrations of the four propolis extracts, and the growth inhibition was then calculated. MIC: Minimal Inhibitory Concentration; MFC: Minimal Fungicidal Concentration; GP_EtOH: green propolis ethanolic extract; GP_US: green propolis ethanolic extract pre-treated with ultrasound; RP_ EtOH: red propolis ethanolic extract; RP_US: red propolis ethanolic extract pre-treated with ultrasound

\begin{tabular}{|c|c|c|c|c|c|c|c|c|c|}
\hline \multirow[t]{2}{*}{ Isolate } & \multirow[t]{2}{*}{ Species } & \multicolumn{2}{|c|}{$\begin{array}{l}\text { GP_EtOH } \\
(\mathrm{mg} / \mathrm{mL})\end{array}$} & \multicolumn{2}{|c|}{$\begin{array}{l}\text { GP_US } \\
(\mathrm{mg} / \mathrm{mL})\end{array}$} & \multicolumn{2}{|c|}{$\begin{array}{l}\text { RP_EtOH } \\
(\mathrm{mg} / \mathrm{mL})\end{array}$} & \multicolumn{2}{|c|}{$\begin{array}{l}\text { RP_US } \\
(\mathrm{mg} / \mathrm{mL})\end{array}$} \\
\hline & & MIC & MFC & MIC & MFC & MIC & MFC & MIC & MFC \\
\hline 2508 & C. albicans & 2 & 4 & 4 & $>8$ & 1 & 2 & 2 & 2 \\
\hline 2517 & C. albicans & 4 & 4 & 2 & 2 & 0.5 & 1 & 1 & 2 \\
\hline 3703 & C. albicans & 4 & 8 & 4 & $>8$ & 0.5 & 4 & 2 & 4 \\
\hline 3704 & C. albicans & 4 & 8 & 2 & 4 & 0.5 & 2 & 0.25 & 2 \\
\hline PAC 01 & C. dubliniensis & 2 & 4 & 2 & $>8$ & 1 & 2 & 2 & 2 \\
\hline PAC 02 & C. tropicalis & 4 & $>8$ & 2 & 2 & 1 & 4 & 0.015 & 2 \\
\hline PAC 04 & C. tropicalis & 1 & 4 & 1 & 2 & 0.125 & 1 & 1 & 2 \\
\hline PAC 05 & C. tropicalis & 4 & $>8$ & 8 & $>8$ & 1 & 2 & 2 & 2 \\
\hline PAC 06 & C. albicans & $>8$ & $>8$ & $>8$ & $>8$ & 4 & $>8$ & 2 & $>8$ \\
\hline PAC 08 & C. albicans & $>8$ & $>8$ & $>8$ & $>8$ & $>8$ & $>8$ & 2 & $>8$ \\
\hline PAC 13 & C. albicans & $>8$ & $>8$ & 4 & $>8$ & 4 & 4 & 1 & $>8$ \\
\hline PAC 15 & C. tropicalis & $>8$ & $>8$ & $>8$ & $>8$ & 4 & $>8$ & 2 & 2 \\
\hline PAC 17 & C. albicans & $>8$ & $>8$ & $>8$ & $>8$ & 2 & $>8$ & 1 & 2 \\
\hline PAC 18 & C. albicans & $>8$ & $>8$ & $>8$ & $>8$ & 2 & $>8$ & 2 & 2 \\
\hline PAC 19 & C. albicans & $>8$ & $>8$ & $>8$ & $>8$ & 1 & 1 & 0.015 & 0.125 \\
\hline PAC 20 & C. albicans & $>8$ & $>8$ & 4 & $>8$ & 1 & 2 & 1 & 2 \\
\hline
\end{tabular}

The evaluation of all Candida spp. oral isolates and reference strains used in this study showed that C. albicans had a great variability for fluconazole susceptibility, with MIC values ranging from 0.25 to $16 \mu \mathrm{g} / \mathrm{mL}$. Eight C. albicans and three C. tropicalis were susceptible to fluconazole (MIC $\leq 2 \mu \mathrm{g} / \mathrm{mL}$ ); one $C$. albicans and one C. tropicalis were resistant (MIC $\geq 8 \mu \mathrm{g} / \mathrm{mL}$ ); and two C. albicans $(\mathrm{MIC}=4 \mu \mathrm{g} / \mathrm{mL}$ ) and one C. dubliniensis $(\mathrm{MIC}=32 \mu \mathrm{g} / \mathrm{mL})$ were fluconazole S-DD. The fluconazole MFCs for $C$. albicans were markedly variable, ranging from 0.125 to undetermined values $(>64 \mu \mathrm{g} / \mathrm{mL})$. Eight of all C. albicans (8/11) showed MFC ranging from 0.125 to $16 \mu \mathrm{g} / \mathrm{mL}$, and three (3/11) could not be determined $(>64 \mu \mathrm{g} / \mathrm{mL})$. Considering the NCA species, the MFC for the C. dubliniensis isolate could not be determined (MFC $>64 \mu \mathrm{g} / \mathrm{mL}$ ). Finally, C. tropicalis fluconazole MFC was determined for two isolates $(\mathrm{MFC}=0.5$ and $16 \mu \mathrm{g} / \mathrm{mL}$ ) and undetermined for the other two isolates $(>64 \mu \mathrm{g} / \mathrm{mL})$ (Table 1$)$.

The fungistatic effect of ketoconazole was observed at low concentrations for all $C$. albicans strains $(\mathrm{MIC}=0.03125$ to $0.125 \mu \mathrm{g} / \mathrm{mL})$. However, the MFC was undetermined for four $(4 / 11)$ of the $C$. albicans specimens (MFC $>64 \mu \mathrm{g} / \mathrm{mL}$ ), being all of them clinical isolates. Regarding the other seven (7/11) C. albicans, four reference strains and three clinical isolates presented
MFC ranging from 0.03125 to $1 \mu \mathrm{g} / \mathrm{mL}$. C. dubliniensis presented ketoconazole MIC of $0.03125 \mu \mathrm{g} / \mathrm{mL}$ and MFC of $0.125 \mu \mathrm{g} / \mathrm{mL}$. Regarding the C. tropicalis isolates, the MIC were 0.03125 and $0.25 \mu \mathrm{g} / \mathrm{mL}$, and MFC were found for two isolates, with values of 0.03125 and $0.125 \mu \mathrm{g} / \mathrm{mL}$, but it could not be determined (MFC $>16 \mu \mathrm{g} / \mathrm{mL}$ ) for the other two isolates (Table 1). Since the M27-S4 document [35] do not provide a ketoconazole susceptibility classification, this specific classification could not be performed to this drug in this study.

Of the three azoles drugs tested in this study, itraconazole was the one that it could be observed a higher number of resistant isolates. Of the 16 C. albicans specimens, four reference strains and 12 clinical isolates, only seven $(7 / 16)$ were susceptible (MIC $\leq 0.125 \mu \mathrm{g} / \mathrm{mL}$ ), and one of the four $C$. tropicalis was susceptible to this drug $(\mathrm{MIC}=0.03125 \mu \mathrm{g} / \mathrm{mL})$. Of the remaining Candida specimens tested, six isolates were resistant (MIC $\geq 1 \mu \mathrm{g} / \mathrm{mL}$ ): three C. albicans, two C. tropicalis and the C.dubliniensis isolate; two $(2 / 16)$ C. albicans $(\mathrm{MIC}=0.25 \mu \mathrm{g} / \mathrm{mL})$ and one C. tropicalis (MIC $=0.25 \mu \mathrm{g} / \mathrm{mL}$ ) were S-DD to itraconazole (Table 1). The fungicidal concentration (MFC) of itraconazole could be determinate for eight $(8 / 11)$ of the $C$. albicans tested, ranging from 0.03125 to $8 \mu \mathrm{g} / \mathrm{mL}$. For the other three C. albicans (3/11) isolates, the MFC could not be determined (MFC $>16 \mu \mathrm{g} / \mathrm{mL}$ ), and these 
three clinical isolates were resistant to itraconazole. For three (3/4) C. tropicalis isolates, the fungicidal concentration for itraconazole was determined (ranging from 0.03125 and $8 \mu \mathrm{g} / \mathrm{mL}$ ). For one C. tropicalis and the $C$. dubliniensis isolate, the MFC could not be determined (MFC $>16 \mu \mathrm{g} / \mathrm{mL}$ ).

Nystatin and amphotericin $\mathrm{B}(\mathrm{AmB})$ presented the lowest variabilities in the MIC and MFC values for all Candida spp. tested in this study. As for itraconazole, nystatin and AmB do not have a susceptibility classification in the M27-S4 document. All C. albicans presented MIC between 1 and $16 \mu \mathrm{g} / \mathrm{mL}$ and MFC ranging from 4 to $16 \mu \mathrm{g} / \mathrm{mL}$ for nystatin, except for PAC17 that presented a not determined MFC $(>16 \mu \mathrm{g} / \mathrm{mL})$. C. glabrata had a nystatin MIC of $2 \mu \mathrm{g} / \mathrm{mL}$ and MFC of $4 \mu \mathrm{g} / \mathrm{mL}$. Regarding the response of $C$. tropicalis to nystatin, the MIC ranged from 0.5 to $2 \mu \mathrm{g} / \mathrm{mL}$, and the MFC ranged from 2 to $4 \mu \mathrm{g} /$ $\mathrm{mL}$. Interesting, AmB had equal MIC and MFC values for almost all strains (Table 1). The AmB MIC for C. albicans ranged from 0.25 to $4 \mu \mathrm{g} / \mathrm{mL}$ and the MFC ranged from 0.5 to $4 \mu \mathrm{g} / \mathrm{mL}$. For $C$. dubliniensis, the MIC and the MFC were the same $(2 \mu \mathrm{g} / \mathrm{mL})$. Finally, for C. tropicalis isolates, the MFC ranged from 0.25 to $2 \mu \mathrm{g} / \mathrm{mL}$, and the MFC ranged 0.5 and $4 \mu \mathrm{g} / \mathrm{mL}$.

When analyzing each isolate alone, it can be seen that the clinical isolate $C$. albicans PAC 17 presented the highest MIC and MFC concentrations for all commercial drugs tested. Thus, this isolate can be considered a potential multidrug resistant organism (Table 1).

\section{Susceptibility to Brazilian green and red Propolis}

All green and red propolis extracts evaluated herein induced growth inhibition in all Candida spp. specimens tested in this study (Fig. 1). However, both red propolis extracts were more effective in lower concentrations when compared to the green propolis extracts

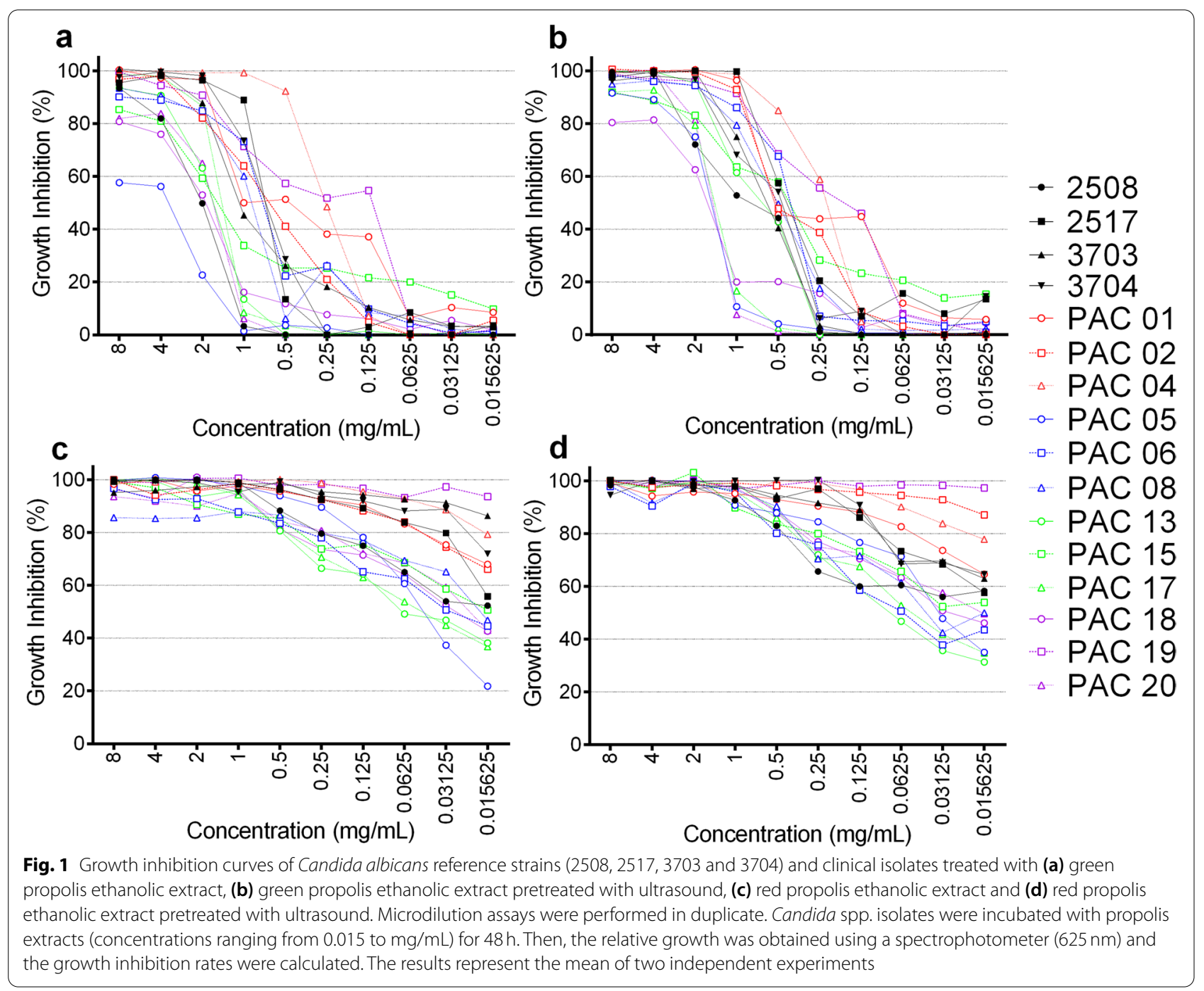


(Figs. 1 and 2). The dose-response curves showed that all Candida spp. had a higher tolerance to both green propolis extracts in lower concentrations; however, above $0.125 \mathrm{mg} / \mathrm{mL}$, the growth inhibition was $\geq 50 \%$, and it was above $95 \%$ at $8 \mathrm{mg} / \mathrm{mL}$ (Fig. 2 - a and b). In contrast, both red propolis extracts, with and without ultrasound pretreatment, presented a higher activity even in the lowest concentration tested $(0.015 \mathrm{mg} / \mathrm{mL})$ (Fig. 2 - $\mathrm{c}$ and d).

The green propolis extracted with different pretreatments were tested against the reference strains 2508, 2517, 3703 and 3704, and the MIC values of GP_EtOH and GP_US ranged from 2 to $4 \mathrm{mg} / \mathrm{mL}$ (Table 2). However, when we evaluated the MFC for GP_EtOH ( 4 to $8 \mathrm{mg} / \mathrm{mL}$ ), it could be determined for all reference strains, while for GP_US the MFC ( 2 to $>8 \mathrm{mg} / \mathrm{mL}$ ) could not be determined for two (2508 and 3703) of the four reference strains (Table 2). Concerning the clinical isolates, the MIC and MFC were undetermined for most of the Candida spp. treated with both green propolis extracts.
The percentage of the clinical isolates with undetermined MIC and MFC values were $66.7 \%(8 / 12)$ and $83.3 \%$ $(10 / 12)$ for GP_EtOH and 50\% (6/12) and 83.3\% (10/12) for GP_US. Only the C. dubliniensis and three C. tropicalis (3/4) isolates had a defined MIC for GP_EtOH, with values ranging from 1 to $4 \mathrm{mg} / \mathrm{mL}$. Regarding MFC values, only the C. dubliniensis $(\mathrm{MFC}=4 \mathrm{mg} / \mathrm{mL}$ ) and one of the C. tropicalis clinical isolates $(\mathrm{MFC}=4 \mathrm{mg} / \mathrm{mL}$ ) presented a defined MIC for GP_EtOH. The response to GP_US by the clinical isolates showed two $C$. albicans (2/7), the C.dubliniensis isolate and the three C. tropicalis (3/4) with defined MICs, with values ranging from 1 to $8 \mathrm{mg} / \mathrm{mL}$. When considering these specific isolates, only two C. tropicalis isolates presented determined MFC values $(2 \mathrm{mg} / \mathrm{mL})$ (Table 2$)$.

For the red propolis extracts (Table 2), the MIC values were 0.5 and $1 \mathrm{mg} / \mathrm{mL}$ for RP_EtOH and 0.25 to $2 \mathrm{mg} /$ $\mathrm{mL}$ for RP_US, when considering the reference strains. For these same strains, the MFC ranged from 1 to $4 \mathrm{mg} /$
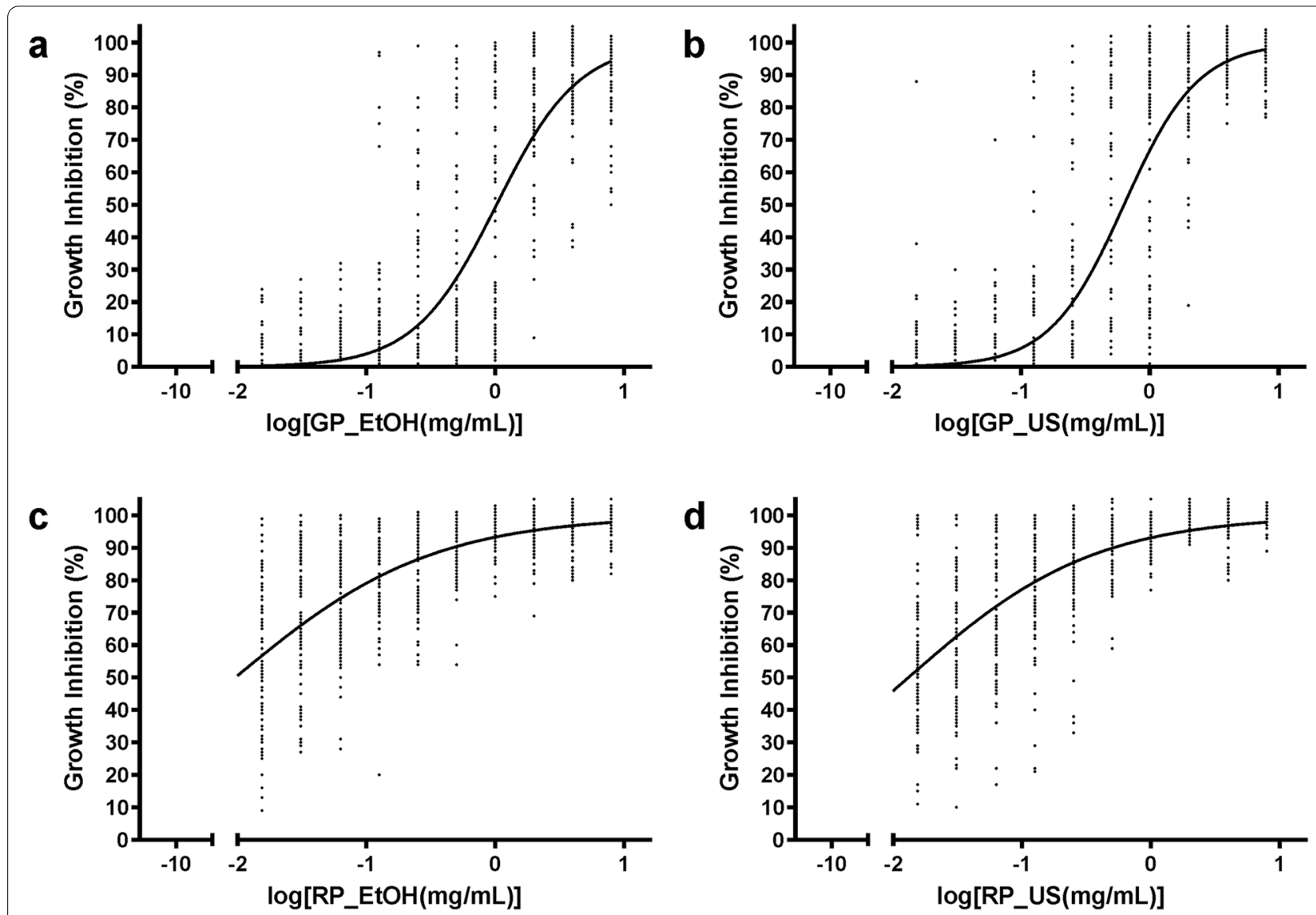

Fig. 2 Dose-response curve of Candida spp. treated with (a) green propolis ethanolic extract, (b) green propolis ethanolic extract pretreated with ultrasound, $(\mathbf{c})$ red propolis ethanolic extract and $(\mathbf{d})$ red propolis ethanolic extract pretreated with ultrasound. Microdilution assays were performed in duplicate. Candida spp. were incubated with a range of propolis concentrations ( 8 to $0.015 \mathrm{mg} / \mathrm{mL}$ ) for $48 \mathrm{~h}$. Then, the relative growth was obtained using a spectrophotometer $(625 \mathrm{~nm})$, and the growth inhibition rates were calculated. Graphical representations and dose-response stimulation statistics were obtained using the software Graph Pad Prism 6 
$\mathrm{mL}$ for RP_EtOH, and 2 to $4 \mathrm{mg} / \mathrm{mL}$ for RP_US. The Candida spp. clinical isolates presented a large variability in the MIC and MFC values for both red propolis extracts evaluated. Only $8.3 \%(1 / 12)$ of clinical isolates tested with RP_EtOH presented an undetermined MIC $(>8 \mathrm{mg} / \mathrm{mL}$ ). This percentage corresponded to juts one C. albicans isolate (PAC 08). The other C. albicans clinical isolates (6/7) presented MIC values between 1 and $4 \mathrm{mg} / \mathrm{mL}$ for RP_EtOH. Of these C. albicans isolates, only three (3/7) had MFC defined values ranging from 1 to $4 \mathrm{mg} / \mathrm{mL}$ for RP_EtOH. The C. dubliniensis isolate had a MIC of $1 \mathrm{mg} / \mathrm{mL}$ and MFC of 2 for RP_EtOH. C. tropicalis isolates presented a MIC ranging from 0.125 to $4 \mathrm{mg} / \mathrm{mL}$, and MFC from 1 to $4 \mathrm{mg} / \mathrm{mL}$ for three of them, and undefined for one isolate (MFC $>8 \mathrm{mg} / \mathrm{mL}$ ) (Table 2). For RP_US, all MIC values could be determined below $8 \mathrm{mg} / \mathrm{mL}$, ranging between 0.015 to $2 \mathrm{mg} /$ $\mathrm{mL}$ for the clinical isolates. Interesting, the C. albicans PAC 19 presented the lowest values for MIC and MFC for RP_US. A MFC $>8$ was observed in $41.7 \%(5 / 12)$ and $25 \%(3 / 12)$ of the clinical isolates for RP_EtOH and RP_US, respectively.

An interesting finding of this study was the susceptibility to the red propolis extracts of the clinical isolate PAC 05 (C. tropicalis), PAC 17 and PAC 19 (C. albicans) isolates, since they presented resistance to fluconazole and itraconazole (Tables 1 and 2). Specifically, the clinical isolate C. albicans PAC 17, besides presenting resistance to the azoles herein included, also presented high MIC and MFC values for the other commercial drugs tested herein (Table 1).

\section{Biofilm formation interference by red Propolis}

The red propolis ethanolic extract was able to interfere in the biofilm formation by all the three strains tested in this specific assay (Fig. 3a, b and c). In all cases, the concentration of $8 \mathrm{mg} / \mathrm{mL}$ induced the highest interference values, reaching the maximum of $89.8 \%$. The concentration of $16 \mathrm{mg} / \mathrm{mL}$ caused interferences in the readings by the spectrophotometer since it condensed in the bottom of the wells. C. dubliniensis (PAC 1) (Fig. 3 - b) was the least susceptible isolate when compared to the other ones tested in the assay, but even so, its biofilm formation was reduced by $78 \%$ at the concentration of $2 \mathrm{mg} / \mathrm{mL}$. Regarding the other two strains $-C$. albicans (Fig. 3a) and C. tropicalis (Fig. 3c), the treatment with the red propolis ethanolic extract at the lowest concentration tested $(4 \mathrm{mg} / \mathrm{mL})$ presented interference results of 65.4 and $72.9 \%$, respectively.

\section{Discussion}

Denture stomatitis is an infection of the oral cavity characterized by inflammation and erythema, being the fungi from the Candida genus important etiologic agents of the disease [38]. The presence of Candida albicans and Candida-non albicans in these infections have been already described $[39,40]$. The identification of these species is usually based on the use of a chromogenic medium which has been described as a good accurate method [30, 41]. However, the molecular approach represents a more accurate method for species identification [42]. Our results showed the presence of three Candida species isolated from denture stomatitis lesions, being $C$. albicans the most frequent species and, in a lower abundance, C. tropicalis and C. dubliniensis. C. albicans and C. tropicalis species were found with a similar frequency
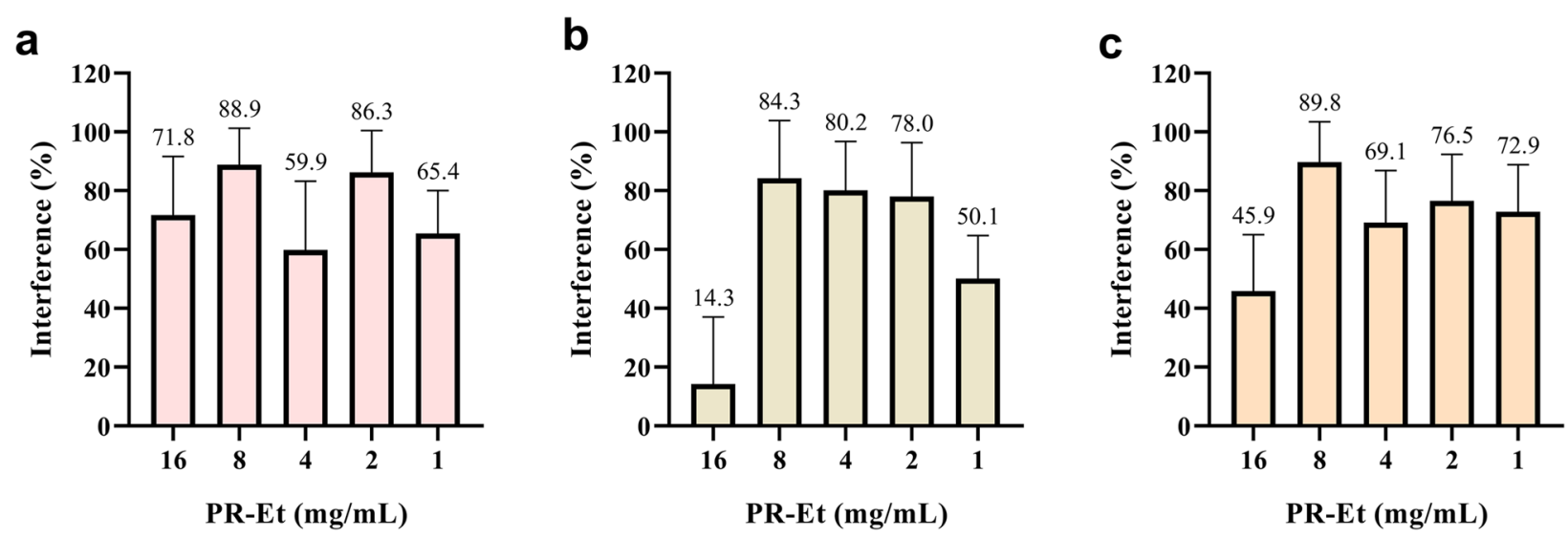

Fig. 3 Interference (\%) of red propolis ethanolic extract in the biofilm formation by (a) C. albicans (PAC 08), (b) C. dubliniensis (PAC 01) and (c) C. tropicalis (PAC 15). The experiment was performed in quadruplicate. The graphical representation was obtained using the software GraphPad Prism 6 
causing chronic periodontitis at Alagoas [3], a Brazilian state close to Bahia state, where this study was conducted. In Pará state, Brazil, C. albicans was also the most frequent species associated with this oral disease, with a $78 \%$ frequency; additionally, C. tropicalis, C. famata and C. parapsilosis were also found, but in association with C. albicans at the infection site [39]. In Spain, C. albicans corresponded to $70 \%$ of Candida specimens isolated from oral candidiasis cases, followed by C. glabrata (8.6\%), C. parapsilosis (7.4\%) and C. tropicalis (3.3\%) [41].

The main drugs used to treat denture stomatitis are miconazole, fluconazole, itraconazole, nystatin, amphotericin $\mathrm{B}$, ketoconazole, clotrimazole and chlorhexidine [43]. In this way, this study used five important commercial drugs that are routinely used for oral candidiasis treatment. Our results showed a great variability in $C$. albicans susceptibility to fluconazole. Besides this, most of the isolates were susceptible to this drug. Siqueira and collaborators [3] showed that some clinical oral isolates of $C$. albicans presented a great variability in fluconazole susceptibility, and the occurrence of resistance in 36.8\% of the Candida spp. isolates tested. In yeasts isolated from bloodstream infections, fluconazole susceptibility tests have demonstrated that $19 \%$ of the isolates were resistant to fluconazole [44]. In addition, the susceptibility test to antifungal agents against $C$. albicans and NCA isolates, when using the criteria of the CLSI document M27-S4, has shown an 2.4-fold increase in the number of species not susceptible to these drugs, when compared to the criteria of document M27-A3 [45].

Regarding the NCA species studied herein and its susceptibility profiles to fluconazole and itraconazole, different patterns were observed. Fluconazole resistance is more common in NCA species than in C. albicans [44, 46]. Despite this, no correlation between the phylogenetic distribution of Candida isolates and the susceptibility profile fluconazole has been found [47]. Omran et al. [40] observed that C. albicans, C. glabrata and C. tropicalis isolated from Iranian patients with denture stomatitis presented 15.5, 17.4 and $12.5 \%$ of in vitro resistance to fluconazole, respectively. As other NCA species, C. $d u b-$ liniensis was associate to infections in immunocompromised patients $[48,49]$. C. dubliniensis azoles resistance cases were already demonstrated in few studies [50, 51]; an in vitro induction of fluconazole-resistance showed that $C$. dubliniensis can easily develop resistance to this drug [50]. Nevertheless, the increase in fluconazole-less susceptible or resistant Candida strains indicates that the use of alternative drugs in the treatment of oral candidiasis is urgently needed $[9,10]$.

The results obtained in ketoconazole susceptibility assays showed lower MIC values. However, the MFC evaluation showed that this drug failed to present a fungicidal effect against the Candida spp. clinical isolates. Ernst and collaborators [52] showed that fluconazole was fungistatic against $C$. albicans and Candida neoformans, but without measurable fungicidal activity. For Trichosporon asahii, azoles showed a fungistatic effect, but without fungicidal activity [53]. The absence of a fungicidal effect can lead to the selection of resistant lines and consequent treatment failure, increasing the number of relapse cases [54].

Our data showed a great variability in the nystatin MIC and MFC values. However, different to what were observed for the azoles, all MIC values for nystatin and Amphotericin B (AmB) could be determined and, except for one $C$. albicans isolate for nystatin, all isolates had their MFC values determined. Nystatin and AmB are antifungals from the polyene class and its activity is associated to the membrane ergosterol content [54]. Miranda-Cadena et al. [41] showed that nystatin presented an excellent antifungal activity against all tested isolates, in opposition to fluconazole and itraconazole. Regarding AmB, our results still showed similar MIC and MFC values in almost all Candida isolates. In a previous study, C. albicans presented $71 \%$ agreement between MIC and MFC values after exposure to AmB [55]. This situation suggests that the same concentration of the drug is able to inhibit the growth and to kill the fungi, as well as facilitate the treatment of the disease, since the drug concentration can be more effective in the control of the fungal spread.

The evaluation of the Brazilian green and red propolis extracts dose-response curves indicated that both red propolis extracts are potent agents against Candida spp. when compared to the green propolis extracts. The antimicrobial activity of the propolis extracts is attributed to the phenolic and flavonoid content $[17,20]$. Several researchers have reported that different propolis extracts present antifungal [18], antimicrobial [18, 56], antitumoral [57], antioxidant [58], anti-inflammatory and immunomodulatory properties $[17,59]$. Green propolis extract activities have been associated in part to artepillin $\mathrm{C}$, a cinnamic acid derivative present in high amounts in Brazilian green propolis samples [20,58]. Artepillin C is considered one of the main active components of the green propolis extracts and exhibits antitumor [60], antiinflammatory [61] and antimicrobial activities [62].

The chemical composition of the green and red propolis ethanolic extracts $[20,32]$ and of the red and green propolis ultrasound-assisted extracts used in this study [32], focused in compounds that have already been cited as having antimicrobial activities, are shown at the Supplementary Table 1 . The isoflavonoid formononetin was found in the in Brazilian green propolis ethanolic extract at the concentration of $4 \mathrm{mg} / \mathrm{g}$ [20], while red propolis 
ethanolic extracts presented $8.68 \mathrm{mg} / \mathrm{g}$ of this compound [32]. For propolis extracts submitted to ultrasound pretreatment, formononetin was present at concentrations of $7.77 \mathrm{mg} / \mathrm{g}$ in green propolis and $8.40 \mathrm{mg} / \mathrm{g}$ in red propolis [32]. Red propolis ethanolic extracts showed almost two times more formononetin when compared to green propolis ethanolic extracts, while the green and red propolis ultrasound-treated extracts present almost the same formononetin concentration. This compound is considered one of the major active components of the red propolis extract due to its diverse biological activities [18, 20, 63-65]. Thus, the high formononetin content of the red propolis can be associated to the best Candida growth inhibition by red propolis when compared to green propolis, and this situation can be supported by the results presented by the treatment with the ultrasoundtreated extracts.

Regarding total phenolic compounds and flavonoids, both green and red propolis ethanolic extracts demonstrated to have high contents of these compounds. Green propolis ethanolic extracts showed a concentration of $181.71 \mathrm{mg}$ EAG/g for total phenolic compounds [20] and $46.80 \mathrm{mg} \mathrm{EQ/g}$ of flavonoids [20], while ultrasound treated green propolis extracts had $342.09 \mathrm{mg}$ EAG/g and $22.68 \mathrm{mg} E Q / g$ of total phenolic compounds and flavonoids, respectively. Red propolis ethanolic extracts presented concentration of $308.49 \mathrm{mg}$ GAE/g of total phenolic compounds and $82.87 \mathrm{mg} \mathrm{EQ} / \mathrm{g}$ of flavonoids, while ultrasound-treated red propolis extracts presented $314.75 \mathrm{mg} \mathrm{GAE} / \mathrm{g}$ of total phenolic compounds and $90.38 \mathrm{mg} \mathrm{EQ} / \mathrm{g}$ of flavonoids [32]. The green propolis extract obtained using ultrasound-assisted extraction has more total phenolic compounds than the ethanolic extract. Red propolis do not showed any differences in total phenolic compound concentration in the extracts obtained by both extraction methodologies. However, when the flavonoids content was compared, the green propolis ethanolic extract has more of this compound than the ultrasound-assisted extract. Red propolis, independently of the extraction method used, had higher contents of flavonoids when compared to green propolis, presenting two and four-fold more flavonoids than green propolis ethanolic and ultrasound extracts, respectively. Propolis antifungal activity have been associated to the high flavonoid content found in different propolis extracts $[66,67]$. Considering that the antifungal activity of red propolis extracts were superior to the green propolis extracts in our study, we can associate this better result to the higher contents of flavonoids and formononetin of red propolis.

The comparison between green and red propolis extract activity against Candida spp. showed that both red propolis extracts had more fungistatic and fungicidal activity than the green propolis extracts. The scientific literature reports a strong red and green propolis antifungal activity against Candida spp. [18]. A variability in antimicrobial and antitumoral activities of colored propolis extracts have already been described, but the green and red propolis showed better results when compared to the yellow or brown propolis extracts [20,68].

The ultrasound pretreatment in red propolis was able to enhance the final concentration of the isoflavones formononetin (60\% increase) and kaempferol (undetectable in red propolis extracts without ultrasound pretreatment), when compared to extracts without this pretreatment [32]. However, even with these higher concentrations of antimicrobial compounds in RP_US, our results showed that just one strain that had MIC $>8 \mathrm{mg}$ / $\mathrm{mL}$ when treated with RP_EtOH presented a MIC of $2 \mathrm{mg}$ / $\mathrm{mL}$ after exposure to RP_US, and the MFC values of the RP_US presented two fewer undetermined results. This situation can be explained based on the study by Neves et al. [69], where it was found that the acetate fraction of red propolis extracts presented an increased concentration of formononetin, but these fractions did not show a higher fungicidal activity against Candida spp. These authors suggested that the antimicrobial activity of red propolis extracts cannot be attributed to just one compound, but is a result of a synergistic effect of them [70].

Our data also showed fungistatic and fungicidal activities of the red propolis extracts against Candida spp. that were resistant to fluconazole and itraconazole. In another study, some NCA strains from Rio Grande do Sul, Brazil, selected in a fluconazole resistance step-by-step assay, showed a cross-resistance to itraconazole and an increase in the MIC for ketoconazole, but no change in the susceptibility to red propolis extracts [69]. A clinical trial using a gel and a mouthwash containing green propolis in the treatment of denture stomatitis showed that these treatments had the same effectiveness against Candida spp--associated denture stomatitis as a miconazole gel [8]. Pippi and collaborators [71] demonstrated that the red propolis from Minas Gerais State, Brazil, had a synergic effect with fluconazole, increasing up to 16 -fold the fluconazole susceptibility of C. parapsilosis, C. glabrata and a polymicrobial culture formed by a mix of $C$. parapsilosis, C. glabrata, C. krusei and C. tropicalis; all of them resistant to fluconazole.

The ability of propolis to interfere with the consolidation and adherence of the biofilm of Candida species is poorly investigated. However, Tobaldini-Valerio and collaborators [72] observed that green propolis effectively affected the biofilm formation by C. albicans, C. parapsilosis and C. tropicalis, but in a species- and strain-dependent manner. In another study, similar results were obtained for green propolis, and the biofilm 
formation by $C$. albicans was significantly more reduced when compared to C. parapsilosis and C. tropicalis [73]. In our work, the majority of the RP_EtOH concentrations tested were able to reduce biofilm formation (more than $80 \%$ ) in the three species tested herein. Most studies had tested the ability of propolis to act on the already formed biofilm [73-75], but as the CDC advises [76], the best way to fight resistant infections is through prevention. Thus, propolis can be used to prevent colonization on abiotic surfaces and in infections by resistant Candida spp. Moreover, as previously discussed, considering the increase in resistance against commercial antifungal, all these findings indicate that red propolis extract is a promising candidate for the development of an oral candidiasis auxiliary treatment.

\section{Conclusions}

The results herein presented showed higher antifungal activity by red propolis extracts, when compared to green propolis extracts. Moreover, red propolis had a fungistatic and fungicidal effect on clinical isolates of $C$. albicans and NCA that were resistant to fluconazole and itraconazole, showing its potential use as an auxiliary/ adjuvant treatment for oral. Additionally, the ultrasound pretreatment did not improve the antimicrobial activity against Candida spp. Regarding biofilms assays, the ethanolic extract of red propolis was able to reduce the formation of biofilm by commercial antifungal resistant Candida spp. isolates.

\begin{abstract}
Abbreviations
AmB: Amphotericin B; BLAST: Basic Local Alignment Search Tool; DMSO: Dimethyl Sulfoxide; SDD: Dose-Dependent Susceptible; FIOCRUZ: Fundação Oswaldo Cruz; GP_US: Green Propolis extract with ultrasound pretreatment; GP_EtOH: Green Propolis extract without ultrasound pretreatment; MFC: Minimal Fungicide Concentrations; MIC: Minimal Inhibitory Concentrations; NCBI: National Center for Biotechnology Information; NCA: Non-Candida albicans species; OD: Optic Densitometry; PAC: Pacient; PCR: Polymerase Chain Reactions; RP_US: Red Propolis extract with ultrasound pretreatment; RP_EtOH: Red Propolis extract without ultrasound pretreatment.
\end{abstract}

\section{Supplementary Information}

The online version contains supplementary material available at https://doi. org/10.1186/s12906-021-03445-5.

\section{Additional file 1.}

\section{Acknowledgements}

The authors are profoundly grateful to Francisca Soares (LABIMUNO ICS/UFBA) for technical assistance. The authors are thankful to Fundação de Apoio à Pesquisa e Extensão (FAPEX) for the financial support. We thank the Coordenação de Aperfeiçoamento de Pessoal de Nível Pessoal (CAPES) for the post-doctoral fellowship for MSF (Programa Nacional de Pós-Doutorado - PNPD).

\section{Authors' contributions}

MAUG, RM, RPCA and RWP designed the study. ARS conducted the sample collection. ARS, MSF, and KRD conducted the laboratory work and data analysis. BAM extracted the green and red propolis used in the study. ARS, MSF and RWP wrote the manuscript. MAUG, RM, and RPCA revised the manuscript. All the authors approved the final manuscript.

\section{Funding}

This study was funded by the Foundation for Research and Extension Support (FAPEX) of the Federal University of Bahia. MSF is a Post-doctoral fellow from the Coordenação de Aperfeiçoamento de Pessoal de Nível Superior (CAPES). RWDP is a Technological Development fellow from CNPq (313350/2019-1).

\section{Availability of data and materials}

All data generated or analyzed during this study are included in this published article and its supplementary information files.

\section{Declarations}

\section{Ethical approval and consent to participate}

All procedures performed in this study involving human participants were in accordance with the ethical standards of the Ethics Committee of the Institute of Health Sciences, Federal University of Bahia, Salvador, Brazil (approval protocol number 2.118.563) and with the 1964 Helsinki declaration and its later amendments or comparable ethical standards. This article does not contain any studies with animals performed by any of the authors. All patients agreed with the study and signed an Informed Consent approved by the Ethics Committee of the Institute of Health Sciences, Federal University of Bahia, Salvador, Brazil (approval protocol number 2.118.563).

\section{Consent for publication}

Not applicable.

\section{Competing interests}

The authors declare that they have no competing interests.

\section{Author details}

1 Programa de Pós-graduação em Processos Interativos de Órgãos e Sistemas. Instituto de Ciências da Saúde, Universidade Federal da Bahia, Salvador, BA 40110-100, Brazil. ${ }^{2}$ Instituto de Tecnologias de Saúde, SENAI/CIMATEC, Salvador, BA 41650-010, Brazil. ${ }^{3}$ Departamento de Biotecnologia, Instituto de Ciências da Saúde, Universidade Federal da Bahia, Avenida Reitor Miguel Calmon s/n, Vale do Canela, Salvador, Bahia State 40110-100, Brazil.

Received: 13 December 2020 Accepted: 19 October 2021

Published online: 24 November 2021

References

1. Mora C, Tittensor DP, Adl S, Simpson AGB, Worm B. How Many Species Are There on Earth and in the Ocean? (2011) PLoS Biol. 9:e1001127. https:// doi.org/10.1371/journal.pbio.1001127.

2. Brown GD, Denning DW, Levitz SM. Tackling human fungal infections. Science. 2012;336:647-7. https://doi.org/10.1126/science.1222236.

3. Siqueira ABS, Rodriguez LRN de A, Santos RKB, Marinho RRB, Abreu S, Peixoto RF, Gurgel BCV. Antifungal activity of propolis against Candida species isolated from cases of chronic periodontitis. Braz Oral Res. 2015;29:1-6. https://doi.org/10.1590/1807-3107BOR-2015.vol29.0083.

4. Gleiznys A, Zdanavičienè E, Žilinskas J, Eglè DDS. Juozas Žilinskas DDS (2015) Candida albicans importance to denture wearers. A literature review. Balt Dent Maxillofac J. 2015;17:54-66.

5. Regezi JA. Ciubba, James J. Jordan RCK. Patologia Oral correlações clinicopatológicas. 7 th. Rio de Janeiro: Guanabara Koogan; 2017.

6. Batista JM, Birman EG, Cury AE. Suscetibilidade a antifúngicos de cepas de Candida albicans isoladas de pacientes com estomatite protética. Rev Odontol da Univ São Paulo. 1999;13:343-8. https://doi.org/10.1590/ S0103-06631999000400005

7. Leite DP, Piva MR, Martins-Filho PRS. Identificação das espécies de Candida em portadores de estomatite protética e avaliação da susceptibilidade ao miconazol e à terapia fotodinâmica. Rev Odontol da UNESP. 2015;44:12-7. https://doi.org/10.1590/1807-2577.1027. 
8. Capistrano HM, de Assis EM, Leal RM, Alvarez-Leite ME, Brener S, Bastos EMAF. Brazilian green Propolis compared to Miconazole gel in the treatment of Candida-associated denture stomatitis. Evidence-Based Complement Altern Med. 2013;2013:1-6. https://doi.org/10.1155/2013/947980.

9. Garcia-Cuesta C, Sarrion-Perez M, Bagan J. Current treatment of oral candidiasis: a literature review. J Clin Exp Dent. 2014;6:e576-82. https:// doi.org/10.4317/jced.51798.

10. Sanguinetti M, Posteraro B, Lass-Flörl C. Antifungal drug resistance among Candida species: mechanisms and clinical impact. Mycoses. 2015;58:2-13. https://doi.org/10.1111/myc.12330.

11. Mukherjee P, Chandra J. Candida biofilm resistance. Drug Resist Updat. 2004;7:301-9. https://doi.org/10.1016/j.drup.2004.09.002.

12. Pereira R, dos Santos Fontenelle RO, de Brito EHS, de Morais SM. Biofilm of Candida albicans: formation, regulation and resistance. J Appl Microbiol. 2021;131:11-22. https://doi.org/10.1111/jam.14949.

13. Holmes AR, Keniya MV, Ivnitski-Steele I, Monk BC, Lamping E, Sklar LA, et al. The monoamine oxidase a inhibitor Clorgyline is a broad-Spectrum inhibitor of fungal $A B C$ and MFS transporter efflux pump activities which reverses the azole resistance of Candida albicans and Candida glabrata clinical isolates. Antimicrob Agents Chemother. 2012;56:1508-15. https:// doi.org/10.1128/AAC.05706-11.

14. Douglas $\sqcup$. Candida biofilms and their role in infection. Trends Microbiol. 2003;11:30-6. https://doi.org/10.1016/S0966-842X(02)00002-1.

15. Chen Y-W, Ye S-R, Ting C, Yu Y-H. Antibacterial activity of propolins from Taiwanese green propolis. J Food Drug Anal. 2018;26:761-8. https://doi. org/10.1016/j.jfda.2017.10.002.

16. Bueno-Silva B, Koo H, Falsetta ML, Alencar SM, Ikegaki M, Rosalen PL. Effect of neovestitol-vestitol containing Brazilian red propolis on accumulation of biofilm in vitro and development of dental caries in vivo. Biofouling. 2013;29:1233-42. https://doi.org/10.1080/08927014.2013. 834050.

17. Rufatto LC, dos Santos DA, Marinho F, Henriques JAP, Roesch Ely M, Moura S. Red propolis: chemical composition and pharmacological activity. Asian Pac J Trop Biomed. 2017;7:591-8. https://doi.org/10.1016/j.apjtb. 2017.06.009.

18. Freires IA, Queiroz VCPP, Furletti VF, Ikegaki M, de Alencar SM, Duarte MCT, et al. Chemical composition and antifungal potential of Brazilian propolis against Candida spp. J Mycol Med. 2016;26:122-32. https://doi.org/10. 1016/j.mycmed.2016.01.003.

19. Gao W, Wu J, Wei J, Pu L, Guo C, Yang J, et al. Brazilian green propolis improves immune function in aged mice. J Clin Biochem Nutr. 2014;55:710. https://doi.org/10.3164/jcbn.13-70

20. Machado BAS, Silva RPD, Barreto G de A, Costa SS, Silva DF da, Brandão HN, Rocha JLC, DEllagostin OA, Henriques JAP, Umsza-Guez MA, Padilha FF. Chemical composition and biological activity of extracts obtained by supercritical extraction and Ethanolic extraction of Brown, green and red Propolis derived from different geographic regions in Brazil. PLoS One. 2016;11:e0145954. https://doi.org/10.1371/journal.pone.0145954.

21. Anjum SI, Ullah A, Khan KA, Attaullah M, Khan H, Ali H, et al. Composition and functional properties of propolis (bee glue): a review. Saudi J Biol Sci. 2019;26:1695-703.

22. Park YK, Alencar SM, Aguiar CL. Botanical origin and chemical composition of Brazilian Propolis. J Agric Food Chem. 2002;50:2502-6. https://doi. org/10.1021/jf011432b.

23. Daugsch A, Moraes CS, Fort P, Park YK. Brazilian red Propolis - chemical composition and botanical origin. Evidence-Based Complement Altern Med. 2008;5:435-41. https://doi.org/10.1093/ecam/nem057.

24. Ferreira JM, Fernandes-Silva CC, Salatino A, Negri G, Message D. New propolis type from north-East Brazil: chemical composition, antioxidant activity and botanical origin. J Sci Food Agric. 2017;97:3552-8. https://doi. org/10.1002/JSFA.8210.

25. Devequi-Nunes D, Machado BAS, Barreto G de A, Silva JR, Silva DF da, Rocha JLC da, Brandão HN, Borges VM, Umsza-Guez MA. Chemical characterization and biological activity of six different extracts of propolis through conventional methods and supercritical extraction. PLoS One. 2018;13:e0207676. https://doi.org/10.1371/JOURNAL.PONE.0207676.

26. Machado BAS, Barreto G de A, Costa AS, Costa SS, Silva RPD, da Silva DF, Brandão HN, Rocha JLC, Nunes SB, Umsza-Guez MA, Padilha FF (2015) Determination of parameters for the supercritical extraction of antioxidant compounds from green Propolis using carbon dioxide and ethanol as co-solvent. PLoS One 10:e0134489. https://doi.org/10.1371/journal. pone.0134489.

27. Chemat F, Rombaut N, Sicaire A-G, Meullemiestre A, Fabiano-Tixier A-S, Abert-Vian M. Ultrasound assisted extraction of food and natural products. Mechanisms, techniques, combinations, protocols and applications. A review. Ultrason Sonochem. 2017;34:540-60. https://doi.org/10.1016/j. ultsonch.2016.06.035.

28. Both S, Chemat F, Strube J. Extraction of polyphenols from black tea conventional and ultrasound assisted extraction. Ultrason Sonochem. 2014;21:1030-4. https://doi.org/10.1016/j.ultsonch.2013.11.005.

29. ANVISA - Agência Nacional de Vigilância Sanitária. Detecção e Identificação dos Fungos de Importância Médica 2004. https://www.anvisa.gov. br/servicosaude/microbiologia/mod_7_2004.pdf. Accessed 7 Aug 2021.

30. Madhavan P, Jamal F, Chong PP, Ng KP. Identification of local clinical Candida isolates using CHROMagar Candida TM as a primary identification method for various Candida species. Trop Biomed. 2011;28:269-74. PMID: 22041745.

31. White T, Bruns T, Lee S, Taylor J. Amplification and direct sequencing of fungal ribosomal RNA genes for phylogenetics. In: Innis M, Gelfand D, Sninsky J, White T, editors. PCR protocols: a guide to methods and applications. New York: Academic Press; 1990. p. 1990. https://www.scien ceopen.com/document?vid=f4505cd7-6ec2-43f4-b1d4-ddee592ba145.

32. Reis JH de O, Barreto G de A, Cerqueira JC, Anjos JP dos, Andrade LN, Padilha FF, Druzian Jl, Machado BAS. Evaluation of the antioxidant profile and cytotoxic activity of red propolis extracts from different regions of northeastern Brazil obtained by conventional and ultrasound-assisted extraction. PLoS One. 2019;14:e0219063. https://doi.org/10.1371/journal. pone.0219063.

33. Clinical and Laboratory Standards Institute (CLSI). M27-S3: Reference Method for Broth Dilution Antifungal Susceptibility Testing of Yeasts; Third Informational Supplement. 3 rd. Wayne, Pennsylvania; 2008. http:// medicine.kaums.ac.ir/UploadedFiles/angalshenase/M27-S3Thirdlnternat ional Supplement.pdf.

34. Rodríguez-Tudela JL, Berenguer J, Martínez-Suárez JV, Sanchez R. Comparison of a spectrophotometric microdilution method with RPMI-2\% glucose with the National Committee for clinical laboratory standards reference macrodilution method M27-P for in vitro susceptibility testing of amphotericin B, flucytosine, and flucona. Antimicrob Agents Chemother. 1996;40:1998-2003. https://doi.org/10.1128/AAC.40.9.1998.

35. Clinical and Laboratory Standards Institute (CLSI). M27-S4 - Reference Method for Broth Dilution Antifungal Susceptibility Testing of Yeasts; Fourth Informational Supplement. Wayne, Pennsylvania; 2012. https:// webstore.ansi.org/standards/clsi/clsim27s4.

36. Lohse MB, Gulati M, Valle Arevalo A, Fishburn A, Johnson AD, Nobile CJ. Assessment and optimizations of Candida albicans in vitro biofilm assays. Antimicrob Agents Chemother. 2017;61:e02749-16. https://doi.org/10. 1128/AAC.02749-16.

37. Kalil MA, Santos LM, Barral TD, Rodrigues DM, Pereira NP, Sá M da CA, Umsa-Guez MA, Machado BAS, Meyer R, Portela RW. Brazilian green Propolis as a therapeutic agent for the post-surgical treatment of Caseous lymphadenitis in sheep. Front Vet Sci. 2019;6:399. https://doi.org/10.3389/ fvets.2019.00399.

38. Gendreau L, Loewy ZG. Epidemiology and etiology of denture stomatitis. J Prosthodont. 2011;20:251-60. https://doi.org/10.1111/j.1532-849X.2011. 00698.x.

39. Gauch LMR, Pedrosa SS, Silveira-Gomes F, Esteves RA, Marques-da-Silva SH. Isolation of Candida spp. from denture-related stomatitis in Pará, Brazil. Brazilian J Microbiol. 2018;49:148-51. https://doi.org/10.1016/j.bjm. 2017.07.001.

40. Mahdavi Omran S, Rezaei Dastjerdi M, Zuashkiani M, Mogarabzadeh V, Taghizadeh-Armaki M. In vitro antifungal susceptibility of Candida species isolated from Iranian patients with denture stomatitis. Biomed Res Int. 2018;2018:1-6. https://doi.org/10.1155/2018/3086586.

41. Miranda-Cadena K, Marcos-Arias C, Mateo E, Aguirre JM, Quindós G, Eraso E. Prevalence and antifungal susceptibility profiles of Candida glabrata, Candida parapsilosis and their close-related species in oral candidiasis. Arch Oral Biol. 2018;95:100-7. https://doi.org/10.1016/j.archoralbio.2018. 07.017.

42. Neppelenbroek K, Seó R, Urban V, Silva S, Dovigo L, Jorge JH, et al. Identification of Candida species in the clinical laboratory: a review 
of conventional, commercial, and molecular techniques. Oral Dis. 2014;20:329-44. https://doi.org/10.1111/ODI.12123.

43. Martins KV, Gontijo SM de L. Tratamento da estomatite protética: revisão de literatura. Rev Bras Odontol. 2017;74:215. https://doi.org/10. 18363/rbo.v74n3.p.215.

44. Pereira GH, Müller PR, Szeszs MW, Levin AS, Melhem MSC. Five-year evaluation of bloodstream yeast infections in a tertiary hospital: the predominance of non- C. albicans Candida species. Med Mycol. 2010:48:839-42. https://doi.org/10.3109/13693780903580121.

45. dos Santos ER, Forno CFD, Hernandez MG, Kubiça TF, Venturini TP, Chassot F, et al. Susceptibility of Candida spp. isolated from blood cultures as evaluated using the M27-A3 and the new M27-S4 aproved breakpoints. Rev Inst Med Trop Sao Paulo. 2014;56:477-82. https://doi. org/10.1590/S0036-46652014000600004

46. Mahmoudabadi AZ, Najafyan M, Alidadi M (2010) Clinical study of Candida vaginitis in Ahvaz, Iran and susceptibility of agents to topical antifungal. Pak J Med Sci 26:607-610. www.pjms.com.pk607. Accessed 7 Aug 2021.

47. Sadeghi G, Ebrahimi-Rad M, Mousavi SF, Shams-Ghahfarokhi M, Razzaghi-Abyaneh M. Emergence of non- Candida albicans species: epidemiology, phylogeny and fluconazole susceptibility profile. $J$ Mycol Med. 2018;28:51-8. https://doi.org/10.1016/j.mycmed.2017.12. 008.

48. Schorling SR, Kortinga $H C$, Froschb M, Mühlschlegel FA. The role of Candida dubliniensis in Oral candidiasis in human immunodeficiency virus-infected individuals. Crit Rev Microbiol. 2000;26:59-68. https:// doi.org/10.1080/10408410091154183.

49. Aslani N, Janbabaei G, Abastabar M, Meis JF, Babaeian M, Khodavaisy S, et al. Identification of uncommon oral yeasts from cancer patients by MALDI-TOF mass spectrometry. BMC Infect Dis. 2018;18:24. https://doi. org/10.1186/s12879-017-2916-5.

50. Moran GP, Sullivan DJ, Henman MC, McCreary CE, Harrington BJ, Shanley DB, et al. Antifungal drug susceptibilities of oral Candida dubliniensis isolates from human immunodeficiency virus (HIV)-infected and non-HIV-infected subjects and generation of stable fluconazole-resistant derivatives in vitro. Antimicrob Agents Chemother. 1997;41:617-23. https://doi.org/10.1128/AAC.41.3.617.

51. Ruhnke M. Development of simultaneous resistance to fluconazole in Candida albicans and Candida dubliniensis in a patient with AIDS. J Antimicrob Chemother. 2000;46:291-5. https://doi.org/10.1093/jac/ 46.2.291.

52. Ernst EJ, Klepser ME, Pfaller MA. Postantifungal effects of Echinocandin, azole, and Polyene antifungal agents against Candida albicans and Cryptococcus neoformans. Antimicrob Agents Chemother. 2000;44:1108-11. https://doi.org/10.1128/AAC.44.4.1108-1111.2000.

53. Hazirolan G, Canton E, Sahin S, Arikan-Akdagli S. Head-to-head comparison of inhibitory and fungicidal activities of fluconazole, Itraconazole, Voriconazole, Posaconazole, and Isavuconazole against clinical isolates of Trichosporon asahii. Antimicrob Agents Chemother 2013;57:4841-7. https://doi.org/10.1128/AAC.00850-13.

54. Krishnasamy L, Krishnakumar S, Kumaramanickavel G, Saikumar C. Molecular mechanisms of antifungal drug resistance in Candida species. J Clin Diagnostic Res. 2018;12:DE01-6. https://doi.org/10.7860/ JCDR/2018/36218.11961

55. Lemos J de A, Costa CR, Araújo CR de, Souza LKH e, Silva M do RR, Susceptibility testing of Candida albicans isolated from oropharyngeal mucosa of HIV+ patients to fluconazole, amphotericin B and caspofungin: killing kinetics of caspofungin and amphotericin $B$ against fluconazole resistant and susceptible isolates. Brazilian J Microbiol. 2009:40:163-9. https://doi.org/10.1590/S1517-83822009000100028.

56. Jorge R, Furtado NAJC, Sousa JPB, da Silva Filho AA, Gregório Junior LE, Martins CHG. Brazilian Propolis: seasonal variation of the Prenylated $p$ -Coumaric acids and antimicrobial activity. Pharm Biol. 2008;46:889-93. https://doi.org/10.1080/13880200802370373.

57. Xuan H, Li Z, Yan H, Sang Q, Wang K, He Q, et al. Antitumor activity of Chinese Propolis in human breast Cancer MCF-7 and MDA-MB-231 cells. Evidence-Based Complement Altern Med. 2014;2014:1-11. https://doi.org/10.1155/2014/280120.

58. Pazin WM, Mônaco L da M, Egea Soares AE, Miguel FG, Berretta AA, Ito AS. Antioxidant activities of three stingless bee propolis and green propolis types. J Apic Res. 2017;56:40-9. https://doi.org/10.1080/00218 839.2016.1263496.

59. Machado JL, Assunção AKM, da Silva MCP, Dos Reis AS, Costa GC, Arruda DDS, et al. Brazilian green Propolis: anti-inflammatory property by an Immunomodulatory activity. Evidence-Based Complement Altern Med. 2012;2012:1-10. https://doi.org/10.1155/2012/157652.

60. Messerli SM, Ahn M-R, Kunimasa K, Yanagihara M, Tatefuji T, Hashimoto $K$, et al. Artepillin C (ARC) in Brazilian green propolis selectively blocks oncogenic PAK1 signaling and suppresses the growth of NF tumors in mice. Phyther Res. 2009;23:423-7. https://doi.org/10.1002/ptr.2658.

61. Paulino N, Abreu SRL, Uto Y, Koyama D, Nagasawa H, Hori H, et al. Anti-inflammatory effects of a bioavailable compound, Artepillin C, in Brazilian propolis. Eur J Pharmacol. 2008;587:296-301. https://doi.org/ 10.1016/j.ejphar.2008.02.067

62. Yoshimasu Y, Ikeda T, Sakai N, Yagi A, Hirayama S, Morinaga Y, et al. Rapid bactericidal action of Propolis against Porphyromonas gingivalis. J Dent Res. 2018;97:928-36. https://doi.org/10.1177/0022034518 758034

63. López BG-C, Schmidt EM, Eberlin MN, Sawaya ACHF. Phytochemical markers of different types of red propolis. Food Chem. 2014;146:17480. https://doi.org/10.1016/j.foodchem.2013.09.063.

64. Dantas Silva RP, Machado BAS, Barreto G de A, Costa SS, Andrade LN, Amaral RG, Carvalho AA, Padilha FF, Barbosa JDV, Umsza-guez MA. Antioxidant, antimicrobial, antiparasitic, and cytotoxic properties of various Brazilian propolis extracts. PLoS One. 2017;12:e0172585. https://doi.org/10.1371/journal.pone.0172585.

65. Lima Cavendish R, de Souza SJ, Belo Neto R, Oliveira Paixão A, Valéria Oliveira J, Divino de Araujo E, et al. Antinociceptive and anti-inflammatory effects of Brazilian red propolis extract and formononetin in rodents. J Ethnopharmacol. 2015;173:127-33. https://doi.org/10.1016/j. jep.2015.07.022.

66. Singla RK, Dubey AK. Molecules and metabolites from natural products as inhibitors of biofilm in Candida spp. pathogens. Curr Top Med Chem. 2019;19:2567-78. https://doi.org/10.2174/156802661966619 1025154834.

67. De-Carli AD, Zárate-Pereira P, De-Carli G, Zafalon EJ, Zárate CB de R, Yassumoto LM. Ação da própolis de apis mellifera associada ao fluoreto de sódio sobre o biofilme dental: ensaio clínico duplo cego randomizado. Rev Odontológica do Bras Cent. 2010;19:51. https://doi.org/10. 36065/ROBRAC.V19151.523.

68. Koo H, Gomes BPFA, Rosalen PL, Ambrosano GMB, Park YK, Cury JÁ. In vitro antimicrobial activity of propolis and Arnica Montana against oral pathogens. Arch Oral Biol. 2000;45:141-8. https://doi.org/10.1016/ S0003-9969(99)00117-X.

69. das Neves MVM, da Silva TMS, de Oliveira Lima E, da Cunha EVL, Oliveira E de J (2016) Isoflavone formononetin from red propolis acts as a fungicide against Candida sp. Brazilian J Microbiol 47:159-166.

70. Machado CS, Mokochinski JB, Lira TO De, de Oliveira F de CE, Cardoso MV, Ferreira RG, Sawaya ACHF, Ferreira AG, Pessoa C, Cuesta-Rubio O, Monteiro MC, Campos MS, Torres YR. Comparative study of chemical composition and biological activity of yellow, green, Brown, and red Brazilian Propolis. Evidence-Based Complement Altern Med. 2016:2016:1-11. https://doi.org/10.1155/2016/6057650.

71. Pippi B, Lana AJD, Moraes RC, Güez CM, Machado M, de Oliveira LFS, et al. In vitro evaluation of the acquisition of resistance, antifungal activity and synergism of Brazilian red propolis with antifungal drugs on Candida spp. J Appl Microbiol. 2015;118:839-50. https://doi.org/10. 1111/jam.12746.

72. Tobaldini-Valerio FK, Bonfim-Mendonça PS, Rosseto HC, Bruschi ML, Henriques M, Negri M, et al. Propolis: a potential natural product to fight Candida species infections. Future Microbiol. 2016;11:1035-46. https://doi.org/10.2217/fmb-2015-0016.

73. Bezerra CRF, Assunção Borges KR, Alves R de NS, Teles AM, Pimentel Rodrigues IV, da Silva MACN, Nascimento MDDSB, Bezerra GFB. Highly efficient antibiofilm and antifungal activity of green propolis against Candida species in dentistry materials. PLoS One. 2020;15:e0228828. https://doi.org/10.1371/journal.pone.0228828.

74. Capoci IRG, Bonfim-Mendonça PDS, Arita GS, Pereira RRDA, Consolaro $M E L$, Bruschi ML, et al. Propolis is an efficient fungicide and inhibitor of biofilm production by vaginal Candida albicans. Evidence-Based 
Complement Altern Med. 2015;2015:1-9. https://doi.org/10.1155/ 2015/287693.

75. Nani BD, Sardi J de CO, Lazarini JG, Silva DR, Massariolli AP, Cunha TM, de Alencar SM, Franchin M, Rosalen PL. Anti-inflammatory and anti-Candida effects of Brazilian organic Propolis, a promising source of bioactive molecules and functional food. J Agric Food Chem. 2020;68:2861-71. https://doi.org/10.1021/acs.jafc.8b07304.
76. CDC. Antibiotic Resistance Threats in the United States. Atlanta; 2019. https://doi.org/10.15620/cdc:82532.

\section{Publisher's Note}

Springer Nature remains neutral with regard to jurisdictional claims in published maps and institutional affiliations.
Ready to submit your research? Choose BMC and benefit from:

- fast, convenient online submission

- thorough peer review by experienced researchers in your field

- rapid publication on acceptance

- support for research data, including large and complex data types

- gold Open Access which fosters wider collaboration and increased citations

- maximum visibility for your research: over $100 \mathrm{M}$ website views per year

At BMC, research is always in progress.

Learn more biomedcentral.com/submissions 